\title{
Influence of Work Ethic and Principal Leadership Style on Teacher Performance
}

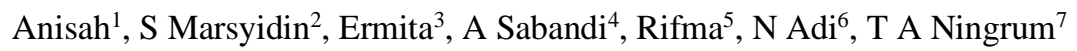 \\ \{anisah@fip.unp.ac.id\} \\ 1,2,3,4,5,6,7 Universitas Negeri Padang, Jl. Prof Dr. Hamka Air Tawar, Padang, Indonesia
}

\begin{abstract}
Teacher performance is assessed annually. In this article, we find out the influence of work ethic and principal leadership style on teacher performance. The method used is a quantitative correlation. The research shows that: (1) work ethic has a direct effect on teacher performance, (2) Principal Leadership has a direct effect on teacher performance, (3) Work ethic through leadership influences teacher performance meaning the higher the work ethic of teachers and the more both the principal's leadership increases the teacher's performance in carrying out the task.
\end{abstract}

Keyword : Influence, Leadership, Teachers.

\section{Introduction}

Teacher performance is very important in the learning process [1] [2] [3]. However many problems are related to teacher performance. This is related to teaching and learning activities not in line with the specified time allocation. Some teachers carry out teaching and learning activities late a few minutes from the specified time and some of them also finish the teaching and learning activities before the time is up. In the implementation of learning, teachers tend to use teaching method of watching a media, without using a variety of teaching methods, and teachers tend to dictate learning materials and students are supposed to take notes. Many teachers do not have a lesson plan that should have been made before carrying out learning. They only make the lesson plan if it will be supervised by a supervisor or principal. Also, many teachers do not have a good work ethic. This can be seen by teachers who often interact with colleagues outside the classroom during the learning process. The phenomenon stated above shows that the work ethic of teachers is still low. If teacher performance is low then the educational goals will be difficult to achieve effectively and efficiently.

Performance is influenced by several factors. One of them is leadership [4]. Then another factor influencing teacher performance is the work ethic [5]. To find out the relationship between these two variables and teacher performance then a study of the Influence of Work Ethic and Principal Leadership Style on Teacher Performance conducted.

\section{Method}

This study uses a correlational research method to comprehend the influence between work ethic and the principal leadership style on teacher performance in Palembayan Junior High School, Agam Regency. The population as a subject of this study were 98 teachers at Palembayan Junior High School, Agam Regency. Sampling is conducted by simple random 
sampling technique. While the number of samples in this study was determined by referring to the Nomogram table proposed by Herry King, namely 66 people with a level of 5\%, the number of samples was 78 people. Then the validity and reliability tests have been carried out with the result that the instruments used are valid and reliable.

\section{Result and Discussion}

\subsection{Result}

\subsubsection{Performance}

Based on the data above, $25.75 \%$ of teachers performance in Pelambayan Junior High School is above the average score namely 17 people, while $16.67 \%$ of teachers performance in Pelambayan Junior High School was in the average score namely 11 people and $57.58 \%$ of teachers performance in Pelambayan Junior High School was below the average score namely 38 people. Based on the questionnaire of teacher performance variables (Y) obtained $81.88 \%$ achievement. It means that the variables of the teacher performance in Palembayan Junior high school are in the "Good" category of ideal scores. To find out the average of each indicator of teacher performance, it can be seen in the following table:

Table 1. Average of teacher performance indicators

\begin{tabular}{clcc}
\hline No. & Indicator & Average & Interpretation \\
\hline 1 & Discipline & 3,98 & Good \\
2 & Punctuality & 4,19 & Good \\
3 & Work initiative & 4,37 & Good \\
Average score & 4,18 & Good \\
\hline
\end{tabular}

In the table above, it can be seen that the highest average score is found in the work initiative indicator, which is 4.37 , which means good. While the lowest average is found in the discipline indicator which is 3.98 but it still means good. In general, the average score of the performance of teachers in the Palembayan Junior high school, Agam Regency is 4.18 which means good.

\subsubsection{Work ethic}

In Table 4, it can be seen that $13.66 \%$ of the work ethic scores are in the average class of 9 people, $16.68 \%$ is above the average class of 11 people and $69.73 \%$ are under the average class of 46 people. Comparison of the average score (mean) with a maximum score multiplied by $100 \%$, then the mean value of 164.88 divided by the maximum score of 175 , then the number $0.85 \times 100 \%=85.00 \%$ is obtained. Thus from the calculation of the work ethic variable score, the teachers in Palembayan junior high school, Agam Regency are in the good category.

Table 2. Average of Work Ethic Indicator

\begin{tabular}{llll}
\hline No. & Indicator & Average & Interpretation \\
\hline 1 & Loyalty & 4,33 & Good \\
2 & Creativity & 4,42 & Good \\
3 & Responsibility & 4,09 & Good \\
Average score & 4,28 & Good \\
\hline
\end{tabular}


In the table above, it can be seen that the highest average of the work ethic variable is in the creativity indicator, which is 4.42 , which means good. While the lowest average of the teacher performance variable is the responsibility indicator, which is 4.09 , which still means good. In general, the average score of the work ethic of teachers in the Palembayan Junior High School, Agam Regency is 4.28 with good category.

\subsubsection{Description of principal leadership style}

From the results of data processing, it is known that the leadership style of the principal obtained a score of $73.1 \%$. This means that the principal's leadership style variable in the Pelembayan Junior High School, Agam Regency is in the "Quite good" category. To get a clear representation of the distribution of the score of principal leadership style variables, see table 7 below:

Table 4. Principal Leadership Style

\begin{tabular}{llll}
\hline No & Research variable & Average & Category \\
\hline 1 & Principal leadership style oriented to task & 3,20 & Quite good \\
& a) Give instructions to teacher & & \\
b) Emphasize the importance of carrying out tasks properly & 3,17 & \\
& c) Instill confidence in the implementation of work & 4,04 & \\
& & 3.47 & \\
\hline $2 \quad$ Principal Leadership Style oriented to Subordinates & 3,52 & Quite good \\
& a) Motivate teacher at work & 3,73 & \\
b) Involve teacher in making decisions & 3,49 & \\
c) Develop a cooperative relationship & 3.58 & \\
& & 3.53 & \\
\hline Total Average & & \\
\hline
\end{tabular}

From the above data, it can be seen that the leadership style of principal oriented to the task is worth an average of 3.47 which means quite good. While the leadership style of principals oriented to subordinates is worth 3.58 which means quite good. The total average value for leadership style is 3.53 which is quite good.

\subsection{Discussion}

Based on the results of the ANOVA test or F test, it produces an F value of 2.052 significance amounting to the significance level of 0.006 . Since the probability of significance is far less than 0.05 , the regression model can be used to predict $Y$ or it can be said that the work ethic (X1) through the principal's leadership (X2) jointly influences the performance of the teacher (Y) in Palembayan Junior High School, Agam Regency.

The results of this study are supported by the opinion of experts such as [6] who suggested that successful teacher performance is supported by a work ethic. Besides that, [7] stated that low performance can also be caused by human factors such as competence, knowledge, skills, work motivation, work ethic, work morale, and low organizational commitment ".

The above opinion states that an influencing factor on teacher performance is the teacher's work ethic. Thus, it can be concluded that the higher the work ethic of the teacher, the higher the teacher's performance. Teacher's work environment is an important factor because it can affect teacher performance. Therefore, to improve teacher performance to be better at work, 
the work ethic of teachers must be further improved, hence teacher performance will be better and organizational goals are achieved to the maximum.

Then, [4] formulated that, "Both the good and bad employees are always associated with leadership. Leaders can influence morale and job satisfaction, security, quality of work-life, and especially the level of achievement of an organization. Based on the description above, it can be concluded that the work ethic and leadership greatly affect teacher performance. The results of this study indicate the influence of work ethic and leadership together to teacher performance. This means that the higher the work ethic and leadership of the principal, the higher the teacher's performance. Conversely the lower the work ethic and leadership of the principal, the lower the teacher's performance.

\section{Conclusions}

Based on these results several conclusions can be drawn as follows:

a) Work ethic has a direct effect on teacher performance. Then, the work ethic of the teacher will increase teacher performance.

b) Principal Leadership directly influences the teacher's performance. The better the principal's leadership, the higher the teacher's performance.

c) The work ethic through leadership influences teacher performance meaning the higher the work ethic of the teacher and the better the leadership of the principal increases the teacher's performance in carrying out the tasks:

\section{Acknowledgment}

Thank you to Universitas Negeri Padang for permitting this research.

\section{References}

[1] Kumala I P, Burhanuddin B and Bafadal I 2018 JAMP: Jurnal Administrasi dan Manajemen Pendidikan 1400

[2] N U Nurmasyitah and Murniati A R 2015 Jurnal Administrasi Pendidikan Program Pascasarjana Unsyiah 3163

[3] M M W Sulistyo, Bambang and Maria M M 2016 Journal of Management 24

[4] B and M Arifin 2012 Kinerja Guru Profesional (Jogyakarta: Ar- Ruzz Media)

[5] A R Riva'i et al 2005 Performance Appraisal (Jakarta: Rajawali Pers)

[6] C W Rusyan T 1994 Kemampuan Guru dalam Proses Belajar Mengajar (Bandung: remaja Rosdakarya)

[7] Wirawan 2009 Evaluasi Kinerja Sumber Daya Manusia Teori Aplikasi dan Penelitian. (Jakarta: Salemba Empat) 